\title{
Løgstrup, värdegrundspedagogerna och det etiska kravet: en kritisk ansats
}

\author{
Av Olof Franck
}

In this article, some significant characteristics of Knud Ejler Løgstrup's analysis of the ethical demand are highlighted, regarding its prominent role in many Swedish representations of value-pedagogical issues. The question if the ethical approach of Logstrup, anchored as it is in a religiously defined foundation, may be judged relevant to the work and activities in a secular educational context is taken as a starting-point. Critical considerations are directed towards an instrumentalisation of the ethical demand, as this is presented by Løgstrup. Parallelly, a way of finding a place and a role for the ethical demand to play in non-confessional value-pedagogical ethics is indicated.

Keywords: Løgstrup, The ethical demand, ethics education, non-confessionality

Olof Franck (F. 1958), Docent i religionsfilosofi, Universitetslektor i de samhällsorienterande ämnenas didaktik og viceprefekt ved Göteborgs universitet, Institutionen för didaktik och pedagogisk profession, Box 300, 40530 Göteborg, Sverige. Epost: olof.franck@gu.se

\section{INLEDNING}

En av de flitigast citerade tänkarna i svenska framställningar om pedagogisk etik är den danske teologen Knud Ejler Løgstrup. De återkommande referenserna till hans bok Den etiske fordring, oftast till den svenska översättningen Det etiska kravet, kan synas närmast samstämmiga. Løgstrup sätter fokus på vad han beskriver som en "naturlig tillit", en hållning som utgör grundförutsättning för människors moraliska samliv. Tanken på en sådan tillit kan lätt låta sig användas som en pedagogisk språngbräda för den som önskar lägga ut texten om hur ett etiskt förhållningssätt i skolan, mellan barn och vuxna, kan och bör utvecklas för att unga människor redan från livets och studiernas början ska kunna växa in i en sådan relation till omvärlden och dess människor, att de ska kunna leva som trygga individer i gemenskap med andra.

Flera av de framställningar som på en svensk arena lyfter fram Løgstrups tänkande kring det etiska kravet knyter detta till frågor rörande "värdegrunden", det vill säga de värden skolans verksamhet ska bygga på: individens frihet och integritet, solidaritet med svaga och utsatta, jämställdhet mellan kvinnor och män och så vidare $^{1}$ Här aktualiseras emellertid frågor om i vilken utsträckning teologiska perspektiv på etik utan konflikt låter sig infogas i en sekulär etisk kontext. Att betrakta etiken och dess radikala krav som förmedlat genom skapelse, och att uppfatta

1 Susanne Hansson analyserar i Den nödvändiga osäkerheten - Elevers perspektiv på begreppet respekt i skolan 69 fjortonåriga elevers tolkningar av begreppet respekt med grund i bland annat Løgstrups etik, och relaterar härvidlag uttryckligen till hur hans resonemang kring människors ömsesidiga beroende eller interdependens kan kasta ljus över centrala dimensioner av begreppet värdegrund. (Hansson 2012). Rebecka Sädbom närmar sig det etiska kravet med hänsyn till hur lärares moraliska intution kan verka i en intensiv och inte okomplicerad klassrumspraktik. Hon relaterar, delvis med referens till den norske pedagogikprofessorn Trygve Bergems tolkning av pedagogiken som en etisk vetenskap (Bergem 2000), den etiska hållning hon tycker sig spåra i Løgstrups "existensetik" till "intuition-i-aktion som existerande yrkesskicklighet". (Sädbom 2007, 167). 
möjligheten att möta detta krav som givet genom en tyst välsignelse av människans liv tillsammans med andra: är dessa teologiskt existentiella motiv relevanta för och förenliga med en icke konfessionell etikundervisning?

Løgstrups tänkande kring det etiska kravet är flerdimensionellt, och det är inte alls märkligt att det kan inspirera till värdegrundsrelaterad reflektion med varierad inriktning. Samtidigt präglas detta tänkande av en svårtillgänglighet, som inte underlättar tolkningen av vad kravet ifråga egentligen handlar om och vad det grundas på. Närmare bestämt föreligger, ska jag i det följande hävda, en risk för att det etiska krav som uppmärksammas i värdepedagogiska framställningar förlorar sitt djup vilket leder till att de teologiska förutsättningar Løgstrup analyserar förringas eller helt elimineras. Kvar står ett etiskt krav som är ett av många tänkbara. I samma stund som den teologiska dimensionen av det krav som Løgstrup kallar radikalt (Løgstrup, 2009:75ff) faller ur blickfånget kommer det att framstå som avradikaliserat, som ett krav bland andra sociala krav - och just detta varnar Løgstrup för i en diskussion kring hur det etiska kravet står ut jämfört med alla andra krav vi människor $i$ våra relationer och $i$ vår samvaro möter och tolkar. (ibid : 86ff) En följd av en sådan avradikalisering är vidare, ska jag hävda, att kravet genom att skildras som skenbart socialt förankrat, riskerar att undslippa en relevant och angelägen filosofisk kritik som manar till varsamhet i utbildningsrelaterade hänvisningar till det.

Jag ska i den här artikeln argumentera för att Løgstrups etiska krav fullt ut kan förstås endast om dess teologiska förutsättningar identifieras, men att detta inte innebär att man måste avstå från att tolka och tillämpa detta krav i sekulära kontexter som exempelvis en icke konfessionell skola. Känner man inte till dess existentiella premisser är det emellertid svårt att upprätta ett förhållningssätt där dess radikala auktoritet vidmakthålls och utvecklas, vilket gör att själva nerven i detta krav vissnar, falnar och leder till en ovälkommen normalisering av dess uppfordrande innebörd. ${ }^{2}$

\section{DET ETISKA KRAVET - BEGREPP OCH TANKESTRÅK}

Grundläggande i Løgstrups tänkande är nästankärlekens skapelseteologiska förankring, den etiska fordrans tysthet och det moraliska ansvarets etik. Som van Kooten Niekerk framhåller, är detta inspirerat av de tyska tänkarna Gogarten och Bultmann. Van Kooten Niekerk menar att originaliteten i Løgstrups tänkande inte ligger i de enskilda idéerna, utan snarare " $i$ Løgstrups forbindelse av de nævnte ideer med vor konkrete livserfaring, hvor især de to nævnte tyske teologer fik tildelt rollerne som sparringspartnere". (van Kooten Niekerk 2007: 31).

Kärnan i det "givna", "tysta" och "radikala" kravet syns fast och konsekvent. För att förstå den behöver man sätta sig in i vad Løgstrup har att säga om begreppet tillit - eller snarare: om förutsättningarna för att uppleva tillit.

I det första kapitlet i Det etiska kravet konstaterar författaren att det för människor är normalt att möta varandra med en känsla av tillit, att denna tillit är "naturlig" därför att människor ger uttryck för den som en omedelbar respons i sådana möten, samt att en skadad naturlig tillit bottnar i upplevelsen av att ha blivit sviken. (Løgstrup 2009:41) Ett sådant svek kan upplevas "våldsamt" därför att detta att visa tillit mot en annan människa är att "utlämna sig själv". (ibid: 42)

När någon missbrukar denna tillit eller när någon inte "tar emot den" (ibid: 42), framstår den måhända som en "fåfäng och kanske meningslös"

2 Jag vill tacka seminariedeltagare i intresseområdet De samhällsvetenskapliga ämnenas didaktik, Institutionen för didaktik och pedagogisk profession vid Göteborgs universitet, för värdefulla synpunkter på en tidigare version av denna artikel. 
yttring som inte blir uppfylld. Jag visar min tillit till en annan människa, hon missbrukar den genom att inte ta emot den vilket leder till reaktionen att jag har blottat min förväntan utan att denna har gått i uppfyllelse. Det framstår i mina ögon som ett nederlag - och som ett svek - och jag kan då vilja göra allt vad jag kan för att försöka dölja det. På så vis kan moraliska förebråelser och beskyllningar göra sitt inträde: "Avvisat självutlämnande ger nämligen", hävdar Løgstrup, "utslag i moraliska domar, därför att situationen är emotionell och enkel och blottorna till varje pris måste döljas”. (ibid: 44).

\section{TVÅ URARTNINGAR AV MÄNNISKORS KOMMUNIKATION}

I många värdegrundspedagogiska framställ-ningar av det etiska kravet inkarneras det i något slag av problematik där maktförhållandet barn - vuxen får exemplifiera hur lätt det kan gå fel i mänskliga relationer, och hur olyckligt detta är just när barn sätter sin tillit till någon vuxen som på ett eller annat sätt missbrukar den. (Gren 2007; Lilja 2013) Det etiska kravet att möta det barn som vänder sig till en i sin utsatthet och sin vilja att bli sedd, blir ett paradigmatiskt exempel på vad detta krav i grunden handlar om. Barnet som möts av tystnad och ett avvisande upplever ett svek som kommer att skada dess naturliga tillit. Spåren av att inte ses, inte räknas, inte inkluderas under respektfyllda förhållanden kan bli långvariga.

Vill man söka en tillämpning av det etiska kravet i skolans relationer mellan barn och vuxna, kan man dock inte formalisera det i termer av mer eller mindre specifika moraliska regler för skolmässig samlevnad. Man måste höja, eller snarare sänka, blicken och se att kravet snarast står för en grundläggande existentiell hållning till livet, det man själv och andra delar. Det betyder att kravet inte heller representerar något slag av vad Karsten M. Hansen har beskrivit som "en ekstrem nominalistisk situasjonsetikk". (Hansen
1996 : 89) Det är inte så att människors moraliska val ur existentiell etisk synvinkel, enligt Løgstrup, renodlat kan betraktas som enskilda aktörers individuellt förankrade beslut rörande moraliska handlingsalternativ. Gud är den samlande kraft som skapar de enskilda situationer på vilka människor har att respondera. Att förstå att livet har sitt ursprung i en allomfattande kärlek och att denna för alla människor givna förutsättning förankrar ett krav på hur var och en väljer att förhålla sig till andra (ibid : 76f), är något annat, något större och något djupare, än att formulera detaljerade regelverk för hur man förväntas agera, och reagera på andras handlingar, i olika specificerade situationer.

Vi människor är alla i varandras makt därför att vi i vår utsatthet och ensamhet när en naturlig tillit som vi hoppas ska besvaras och uppfyllas genom handlingar som berör och visar på omhändertagande och kärlek. Vi blir dock ofta besvikna i det här livet eftersom både vi och andra sviker det etiska kravet genom egoistiska val och självcentrerade handlingar. I det läget kan vi bli utnyttjade, precis som vi själva kan utnyttja andra. Men det är att observera att Løgstrup här inte presenterar någon lista över konkretiserade ignoreranden av det etiska kravet. Det går inte att ge någon sådan precisering. Enskilda människor har i givna situationer att tolka hur de tror att kravet bäst bör ta gestalt där och då. (Løgstrup 2009:75ff; Hansen 1996:214) Kravet är i denna mening, till skillnad från sociala normer, "outtalat"(:53ff). Det ligger inget explicit "du ska" eller "du ska inte" i det. "Det radikala kravet", slår Løgstrup fast, "säger, att den andres liv ska tillvaratas på det sätt som den andre är bäst betjänt av. Något annat och mer säger det inte." (Løgstrup 2009:85) Sociala normer däremot är inte sällan mer exakt föreskrivande för hur man i de eller de situationerna ska agera. (ibid:85)

Att som medmänniska uppleva att man har en annan människas liv i sin hand genom ansvaret 
för att bidra till denna människas väl, visar på ett krav som till skillnad från dem som faller tillbaka på vardagens och samhällets normer för samlevnad, inte kan göras språkligt och moraliskt konkret. Det bör enligt Løgstrup understrykas, att det också betyder att den som försöker gestalta det etiska kravet, inte har vare sig rätt eller möjlighet att föreskriva eller ha synpunkter på hur den människa som kommer i min väg väljer att reagera på min etiska gestaltning. Utifrån min livsförståelse kan jag "inbilla mig att jag bättre än hon vet vad som är bäst för henne”. (ibid:55) Och detta är, menar Løgstrup, att missbruka den makt jag har i min hand när det gäller att vara medmänniskor till hjälp genom att i olika möten tolka det outtalade etiska kravet utifrån min förståelse av livet. (ibid:55)

\section{DET ETISKA KRAVET: SYFTE OCH MÅL}

Kan man av ovanstående dra några slutsatser rörande det etiska kravets relevans för skolans verksamhet och dess relationer? Vi kan konstatera att Løgstrup inte presenterar det som ett moralpedagogiskt arbetsredskap, utan som en grundhållning som är given såsom en förutsättning för människors ömsesidiga samvaro i det liv de delar. Att betrakta kravet ur en sådan här existentiell infallsvinkel gör det kanske svårare att se vilken praktisk relevans det skulle ha för skolans relationer, till exempel i det vi i Sverige kallar "värdegrundsarbete".

Vad som här kan tyckas vara intressant är, för det första, att de värdegrundspedagoger som väljer att referera till Løgstrups framställning om det etiska kravet - av naturliga skäl - har sitt fokus riktat mot en tillämpning av detsamma i sammanhang där barn står i centrum, som i skola och familj. Jag tror dock att det är en brist hos dessa att de inte ser vidare bortom Løgstrups explicita skrivningar om barn och barns tillit när det gäller det etiska kravet. Självfallet ter det sig närliggande - ja, logiskt - att tillämpa kravet på maktrelationer mellan barn och vuxna. Men det är inte detta som Løgstrup har som sitt primära huvudsyfte. Han vill visa att kravet är existentiellt givet med livet som en kärlekens gåva, och att människan genom olika suveräna livsyttringar relaterar till det. Att praktisera kärlek och omsorg är att knyta an till de grundläggande villkor vår existens är förenad med.

\section{DET "ENSIDIGA” ETISKA KRAVETS TYSTHET, SPONTANITET OCH RA- DIKALITET}

Inte sällan återfinner man i värdegrundspedagogiska framställningar en kritik av, eller åtminstone en undran över, varför Løgstrup bestämmer det etiska kravet som "tyst" och "outtalat", "spontant" och "radikalt". (Gren 2007; Lilja 2013) Det är på ett sätt inte underligt att den kritiska frågan reses, givet att det etiska kravet uppfattas som psykologiskt-moraliskt betingat, men för Løgstrup torde det här handla om en existentiellt sett irrelevant icke-fråga. Med det etiska kravet avser han inte att lägga ut texten om vilka psykologiska motiv för och vilka försök att rättfärdiga, alternativt fördöma, olika slag av handlingar som kan framställas och analyseras. Det etiska kravet bärs inte alls av några motiv. Det präglas av en nästankärlek, och har - helt oberoende av människan och hennes göranden och låtanden - sina rötter i det skapade liv som är en gåva till ömsesidighet. Detta är den skapelseteologiska grund som tillskrivs den etiske fordring. Det finns en kraft i var och en av oss, vilken vi inte kan styra av egen vilja utan som vi omfattas av bara genom att vara kännande, handlande människor i samvaro med andra.

Den kraften beskriver Løgstrup som "kärleken till nästan", och den har inte med moraliska påbud, föreskrifter, regelverk, formaliseringar av "rätt" och "orätt” att göra. Till skillnad från "den naturliga kärleken", den beredskap vi har för att ta hand 
om och ta ansvar för våra nära medmänniskor, som våra barn, är nästankärleken inte socialt eller biologiskt förankrad. Det är en i skapelsen nedlagd förmåga som vi inte har förvärvat genom egen kraft, utan har med oss från den stund vi andas det första andetaget. (Løgstrup 2009:172; Hansen 1996:215)

Dess radikalitet har, som David Bugge uttrycker det, en kvalitativ och en kvantitativ dimension. Den förra åsyftar fordringens hur, det vill säga den osjälviskhet med vilken den har att praktiseras i relation till medmänniskor. Den senare refererar till fordringens vem, det vill säga omfattningen av i förhållande till vilka medmänniskor jag har att utöva mitt ansvar, nämligen till var och en, såväl vän som fiende. Den kvantitativa dimensionen följer av den kvalitativa: om förutsättningen för att gestalta det etiska kravet är osjälviskt handlande, kan inte subjekten i förhållande till vilka denna gestaltning sker begränsas till att gälla enbart somliga. (Bugge 2011:80)

"Att visa tillit och utlämna sig, att hysa en naturlig kärlek är godhet. I den meningen tillhör godheten vårt människoliv även om vi är onda. Båda delar gäller fullt ut, så att man inte kan göra ett räkneexempel av det”. (Løgstrup 2009:171) Dessa ord ur Det etiska kravet sätter fokus på vars och ens del av förmågan att, utan att kalkylera, beräkna, kvantifiera, göra gott. Och denna förmåga finns där, som sagt, hos oss från den allra första början: "Det finns inte heller något att lägga till människolivets godhet. Den finns där och finns helt och fullt men på förhand - och alltid på förhand, bland annat i tillitens och kärlekens realiteter". (ibid:171)

Det ligger nära tillhands att tolka denna förmåga som förankrad i en "grund" av teologisk natur. Här är det viktigt att avstå från att psykologisera sådana begrepp som att visa tillit och att utlämna sig, vilket, som jag hävdat tidigare, leder till en instrumentalisering av det etiska kravet. Ja, man kunde rentav tala om ett förtingligande av detsamma, nämligen i så måtto som ett försök att konkretisera vad det står för och vad det förväntas leda kan ses som ett försök att materialisera det som inte kan göras materiellt, fogligt, beräkneligt, möjligt att väga och värdera.

Vad innebär då en sådan här psykologiserande instrumentalisering av Løgstrups existentiella fenomenologi? Denna fråga kan besvaras med referens till hur de centrala begreppen tysthet, spontanitet och radikalitet tolkas, utan förankring i Løgstrups existentiellt fenomenologiska hållning när det gäller att identifiera och utveckla det etiska kravet och dess grundläggande väsen, dess premisser och konsekvenser.

Med att det etiska kravet är "tyst" eller "outtalat" syns Løgstrup avse två ting vilka inte alltid genom hans framställning relateras på ett tillgängligt sätt. Dels syftar det, i den av ömsesidighet burna relationen människanmänniska, på att kravet inte "är liktydigt med den andra människans uttalade önskan eller "krav" (Løgstrup 2009:53), säger Løgstrup. Han går så långt som att säga att det är en tillfällighet om det etiska kravet och önskan och krav och förväntan hos en annan människa på hur hon ska mötas och behandlas sammanfaller. (ibid:53)

Men det etiska kravets tysthet eller outtalade väsen syftar också på att det är givet som en existentiellt ofrånkomlig förutsättning, förankrad i livet som en kärlekens gåva till människan, utan pekpinnar, utan materialisering i de eller de regelverken eller de eller de katalogerna över vad som anses "rätt" respektive "orätt" att göra och hänge sig åt. Det ansvarsförhållande mellan etiskt subjekt och etiskt objekt i vilket människan utan möjlighet att vända sig mot, än mindre väja för, befinner sig vara insatt $i$, har genom skapelsen en absolut grund. Det betyder dock inte att denna är fjärmad från det mänskliga livets konkreta utmaningar. Det är i dessa utmaningar den gör sig påmind och ställer människan inför ett etiskt val 
utan att lämna generella antydningar, än mindre föreskrifter, om vilka vägar som kan vara lämpliga att gå.

Det etiska kravets tysthet hör således hemma i den existentiella fenomenologi som Løgstrup låter den djupa etiska samvaron människor emellan vila på. Det är, om man så vill, en andlig fenomenologi, både i det avseendet att det givna, det vi människor har att förhålla oss till i våra grundläggande relationer till varandra, inte kan konkretiseras och fångas i vetenskapligt analytiska och prövbara begrepp (ibid:199ff), och i den meningen att man inte heller kan konkretisera den skapelseprocess i vilken dessa givna storheter - tystheten, det outtalade, det spontana, det radikala etiska kravet - har sin yttersta grund och sin bärande mening.

Denna fenomenologi visar på en väg att gå för att ifrågasätta ett tankemönster där människan själv tillskriver sig det absoluta herradömet över världen och livet i denna, som om dessa var resultat av hennes eget verk. För Løgstrup är det en filosofisk utmaning att på olika områden hantera ett sådant här herradömes- eller maktperspektiv på ett sätt som ger utrymme för människans frihet och ansvar, i en tillvaro vilkens tillblivelse ligger utanför hennes makt att skapa. Men det är också, genom den Guds skapelse som skänkt människan livet som givet, en utmaning med starka teologiska dimensioner. (Christoffersen 1999:18f)

På liknande sätt kan det sägas att det etiska kravet är "spontant" därför att det springer fram ur de givna förutsättningar människors samvaro har, snarare än formuleras utifrån ett bestämt motiv. Sociala krav finns det gott om och de kännetecknas just av att framställas utifrån ett skäl, en anledning, ett syfte, ett motiv: nämligen att inspirera, eller, vilket också kan förekomma, forcera människor att agera på ett visst sätt som anses föredömligt i relation till en viss konsekvens. Som David Bugge framhåller, är Løgstrup inte ute efter att principiellt vilja upphäva sociala normsystem eller undantagslöst kritisera dem. Däremot kan sociala normer inte nå längre än till att vara "vägvisare”. (Bugge 2011:87f) För att kunna ge uttryck för den nästankärlek som inte binds upp av föreskrifter och förbud, krävs mer än vad som görs i de krav som vilar på det sociala samlivets grund. Det etiska kravet är inte ett krav bland andra. Dels förutsätter det till skillnad från åtminstone de flesta sociala normer en total kärlek till den i relation till vilken jag står i begrepp att handla. Dels är de sociala normerna föränderliga: deras form och innehåll har inte likt det etiska kravet en absolut förankring utan är skiftande, vilket också kan ge skäl för framställande av kritik, som när det gäller exempelvis historiskt betingade varianser rörande synen på relationer, roller och rättigheter mellan könen. (ibid:94ff)

Tidigare nämnde Kees van Kooten Niekerk påminner om Gustaf Wingrens kritik av Løgstrups tänkande kring det etiska kravets relation till sociala normer, enligt vilken Løgstrup, i likhet med inspiratören Gogarten, kommer att stötta en konserverande samhällsordning. Om normerna, som Løgstrup gör gällande, ska ses i relation till och uppfattas spegla samhällets institutioner och samtidigt förstås ha en absolut betydelse för hur människor ska kunna konkretisera det etiska kravet, syns ett försvar för en bestående samhällsordning ligga nära tillhands. (van Kooten Niekerk 2007:38)

Løgstrup besvarar denna kritik genom att peka på att han, till skillnad från Gogarten, problematiserar förhållandet mellan det etiska kravet och sociala normer, och att han, som vi i det föregående sett, menar att de senare är föränderliga och att det kan visa sig att de vilat på icke försvarbara grunder. (Løgstrup 1961: 269) van Kooten Niekerk förhåller sig skeptisk till att detta svar övertygar. (van Kooten Niekerk 2007:38) Jag vill för min del mena, att Løgstrup presenterar viktiga poänger som i alla fall inte utan vidare kan avfärdas som respons på Wingrens kritik. 
$\AA ̊$ andra sidan finns här en problematik som kräver ytterligare utredning och analys. Frågan om hur en existentiellt förankrad och teologiskt motiverad etik kan utvecklas blir brännande för den som, med referens till en andlig dimension, önskar förlägga etikens kärna utanför, men i relation till, de historiskt, socialt och kulturellt förankrade normernas och värdenas sammanhang. Här finns inte plats att närmare undersöka denna fråga. Jag nöjer mig därför med att hänvisa till ett annat sammanhang, där jag presenterar en ingång till hur konfliktperspektiv kan tilldelas en bärande roll för utvecklandet av en emancipatorisk, andligt förankrad etik. (Franck 2014b)

\section{DET ETISKA KRAVETS OUPPFYLLBARHET}

Ett annat kännetecken på det etiska kravet är, enligt Løgstrup, dess ouppfyllbarhet, vilket, apropå förutsättningar som skapar utmaningar för den som önskar relatera det etiska kravet till värdegrundspedagogiska kontexter, torde visa sig vara inte helt enkelt att hantera.

Människans oförmåga att leva upp till olika slag av moraliska förväntningar är, i såväl teologisk som filosofisk litteratur om etik, ett klassiskt tema. Løgstrups existentiella etik utgör härvidlag, som antytts, inte något undantag. Och det är inte någon helt okomplicerad bild han ger av förutsättningarna för en etisk ouppfyllbarhet.

På en punkt följer han många religiösa tänkare när de pekar på människans delaktighet inte bara i en god utan också en ond natur. (Løgstrup 2009:196) Att i handling gestalta det etiska kravet i relation till medmänniskor är inte fullt ut möjligt, eftersom människan har sina moraliska begränsningar vilka, precis som hennes moraliska förmågor, är givna såsom förutsättningar för hennes samvaro och gemenskap med andra. Varken förmågan att göra gott eller förmågan att göra ont är förvärvade: de finns med människan från hennes första stund på jorden.
Løgstrup framhåller att "vi inte alls kan tala om det krav som är oss givet med vår tillvaro annat än på antropomorft sätt” (ibid:196) Vi kan bara språkligt fånga det etiska kravet genom att tillskriva det uppfyllbarhet, för det är så vi semantiskt och moraliskt använder oss av ordet "krav". Och Løgstrup ger ett sådant tal en närmast andlig sanktion när han lägger till att

Det är den självklaraste sak $i$ världen att kravet går att uppfylla, därför att det faktum som det kommer sig av, är välsignelsen i våra liv: Att vi inte är lämnade ensamma utan att våra liv hör samman med varandra. Att förakta kravet är därför att förakta välsignelsen. (ibid:196f)

En möjlig tolkning av detta inte helt tillgängliga resonemang är denna. Det finns med människans givna moraliska förutsättningar en "tyst" välsignelse av hennes liv tillsammans med andra, vilken på ett grundläggande plan lyfter en kärleksfull uppfyllelse av det etiska kravet som en möjlig realitet. Gentemot denna välsignelse tar vi inte sällan, säger Løgstrup, stöd och försöker förankra och uttrycka kravet i vårt förhållningssätt till andra. Men vi känner hur vi misslyckas och hur kravet blir oss övermäktigt. Vi känner en besvikelse över att inte nå dit där det faktiskt är möjligt att uppfylla vårt ansvar för andra människors liv. Då känner vi, framhåller Løgstrup, skuld - och vi uppfattar kravet som ouppfylleligt: vi har använt vår kraft och vår strävan att göra gott utan att lyckas helt och fullt. Reaktionen är naturlig: vi känner att vi inte rådde med detta, att vi fastnade i det som skapade hinder på vägen mot kärlekens mål, att vår "onatur" tog överhanden och att vi givet dessa omständigheter inte kommer att lyckas med att låta kravet uppfyllas i våra liv.

\section{VARFÖR INTE KRISTEN ETIK?}

I den mån man här kan tala om en "religiöst förankrad etik" aktualiseras frågan huruvida en 
sådan alls kan relateras till den i läroplanerna föreskrivna icke konfessionella verksamhet som ska bedrivas i svenska skolor (Lgr11:7; Gy11: 5). Jag tror nog att en sådan fråga principiellt kan göra sig påmind också i många andra länders utbildningskontexter: det är långt ifrån bara Sverige som håller sig med ramar för att inte låta religiösa och konfessionella trossatser och normer styra eller vägleda livet i skolan. Möjligen kan det röda ljuset kanske blinka än mer intensivt på svenska breddgrader, åtminstone om man ska tro vad vissa religionsvetare påpekar, nämligen att det svenska samhället präglas av en religionsblindhet, en okunskap om religionens plats och roll i människors liv världen över, vilket då ibland sägs komma till uttryck i ett slags överkänslighet mot att blanda in religiösa föreställningsvärldar i exempelvis det skolförankrade etiska samtalet människor emellan. (Franck 2006)

Hur det än må förhålla sig med detta, är det viktigt att understryka att Løgstrup uttryckligen tar avstånd från att teologisera det etiska samtalet och den etiska samvaron människor emellan. Han understryker dessutom att en religiös tro, vilket $\mathrm{i}$ Løgstrups framställning avser en kristen tro, inte erbjuder vare sig särskilda och "högre" kunskaper om rätt och orätt. Den kristne måste ta ställning till moraliskt svåra frågor och dilemman "på precis samma villkor som alla andra" (Løgstrup 2009: 140). "Kristendomen", slår Løgstrup fast, "utrustar inte den enskilda människan med en politiskt eller etiskt sett högre form av kunskap" (ibid:140).

Men vilken roll spelar då kristen teologi i Løgstrups framställning om det etiska kravet? Som vi sett anger inte religionen gränser för vem som på lika villkor kan och bör delta i en etisk diskussion kring moraliska frågeställningar. Det finns inte, konstaterar Løgstrup, en kristen etik, om med det avses en etik som med grund i kristen troslära och teologi förmår förankra argument för och emot bestämda ståndpunkter, slutsatser och handlingar i människors moraliska liv. Om kristendomen fungerade på så sätt skulle den, säger Løgstrup, ha "stelnat till en ideologi" (ibid : 141). "Menneske først og kristen saa", citerar Gustaf Wingren den danske tänkaren och psalmförfattaren Grundtvig, hos vilken en viktig förankring för Løgstrups tänkande ska sökas. (Wingren 2009 : 21ff) Det betyder dock inte att inte det etiska kravets existentiella grund skulle kunna uttryckas i termer som faller tillbaka på en kristen grundhållning till livet och skapelsen.

Løgstrup vänder sig till kristendomens centralgestalt Jesus såsom, som Wingren uttrycker det, "den enda friska Människan i vår historia” (Løgstrup 2009:19), och pekar på att allt vad han

har sagt och som har traderats till oss, varje berättelse och liknelse, varje svar i ett samtal eller en strid, varje knappt formulerat yttrande är en förkunnelse av det krav som i sig självt är tyst. Detta är det ohanterliga med hans förkunnelse. (ibid:138)

Løgstrup beskriver det som "egendomligt" (ibid: 138) att den ordrika och omfattande förkunnelse Jesus enligt Bibelns ord ger röst åt, i grunden uttrycker allt det etiska kravet i sin tystnad står för. Så varför alla dessa ord om det nu, som vi tidigare sett, är en existentiellt given tystnad som utmärker och bär upp kravet? Jo, svarar Løgstrup, därför att förkunnelsen ifråga säger en enda sak: nämligen att kravet "är Guds": "Därför talar det i tystnaden och varken $\mathrm{i}$ det som den andre eventuellt talar om eller i de normer som vi har enats om skall gälla för allas bästa" (ibid: 138). Svein Aage Christoffersen beskriver denna Løgstrups tanke som att "Jesus opphever anonymiteten". (Christoffersen 1999:50)

David Bugge lyfter fram Løgstrups tanke att Jesu religiösa förkunnelse visar på ett motiv till det etiska kravet, men att detta också är den väsentliga 
roll förkunnelsen har. Man måste, säger Bugge,

Skelne mellem Jesu religiøse forkyndelse (budskabet) og den heri indeholdte holdning til det andet menneske. Hvad det sidste (og kun det) angår, har Jesus ifølge Løgstrup i en viss forstand overflødiggjort sin egen forkyndelse. Når denne nemlig først har afsløret et givet trek ved vores tilvarelse - eller anderledes udtrykt: når Jesus først har skerpet sansen for Guds evige og universelle fordring, hvis radikalitet hidtil har veret overhørt - da kan vi siden kende det af os selv uden forkyndelsens bistand. (Bugge 2011:20)

Løgstrup presenterar ett teologiskt motiv för en filosofisk analys av de grundläggande existentiella villkor Jesu förkunnelse lyfter fram som bärande för en nästankärlek förankrad i en skapelsens fenomenologi där det givna, det vi alla har att förhålla oss till, är det etiska krav som präglas av tysthet, spontanitet, radikalitet och ensidighet. (Løgstrup 2009:20) Det för längre än vad socialt baserade regelverk kan göra, när det handlar om att ta andra människors liv i ens hand och, utan tanke på motprestationer, vara dem man möter till hjälp genom att ta deras naturliga tillit på allvar och möta den med kärlek. "Gud kräver inte annat än vad han själv ger" (ibid:138): i det påståendet uttrycker Løgstrup med en kristen referens hur "välsignelsens gåva" till människan, livet i gemenskap med andra, ger de förutsättningar för att göra gott och handla väl som är nödvändiga för att så långt möjligt uppfylla det etiska kravet.

Som tidigare citerade Svein Aage Christoffersen framhåller, betyder givetvis inte detta att det enligt Løgstrup överhuvudtaget inte skulle föreligga en relation mellan kristendom och etik. Hans skapelseteologiska förankring för det etiska kravet visar på just en sådan relation. Däremot finns inte enligt Løgstrup en kristen "materialetik", en etik som mer eller mindre skulle kunna användas som ett slags facit för att söka sig fram till lösningar på moraliska frågor och problem. (Christoffersen 1999:48)

Och det är, sagt till sist i detta sammanhang, viktigt att se att dessa förutsättningar antas vara desamma för alla människor oavsett om de själva skulle vilja och kunna se dem som uttryck för ett etiskt krav som är "Guds krav". Alla lever och handlar utifrån samma existentiellt givna grundförutsättningar oavsett om de kan och vill ta till sig en religiös terminologi för att fånga dessa förutsättningar. Innebär detta, kan man då fråga, ett problem för den som i en icke konfessionell skola önskar ge utrymme för samtal och kommunikation med grund i det etiska kravet?

\section{VÄRDEGRUND, ETIK OCH MORALPEDAGOGIK}

Jag tror att det är viktigt att här hålla isär två förhållningssätt. Det ena innebär att man i enlighet med en given hållning strävar efter att göra gott och handla väl. Det andra innebär att man också omfattar den ideologiska basen för denna hållning. Jag kan till exempel, för att hålla det på en mycket konkret nivå, finna det vara angeläget att följa den gyllene regeln utan att för den skull förankra det i en personlig religiös tro, kristen eller annan, på samma sätt som jag kan välja att fasta eller ge en viss procent av mina materiella tillgångar till behövande utan att vara troende muslim. Att följa vissa etiska koder eller normer eller förhållningssätt på så att säga ideologiskt pragmatiska grunder, det vill säga utan att mer direkt knyta detta till en religiös övertygelse eller tro, behöver nog i många fall inte vara särskilt komplicerat eller ohanterligt. En troende och en icke troende kan båda finna att den gyllene regeln, hämtad från Bibelns skildringar av Jesu förkunnelse eller från andra religiösa kontexter, till sin kärna är viktig och angelägen att följa, även om den ene exempelvis har en personlig tro på Jesus som frälsare och den andre kanske snarare betraktar Bibelns Jesusgestalt som en moralpredikant med ett angeläget budskap. 
När det gäller det etiska kravet förhåller sig emellertid saker och ting lite annorlunda, inte minst därför att kravet uppfattas som för alla människor givet såsom en existentiell grundförutsättning för ett moraliskt förhållningssätt. När Løgstrup beskriver kravet som "Guds" öppnar han dörren ut mot en andlig, religiös, icke sekulär förankring av detsamma. Och hur han här än understryker att religiösa och icke religiösa, kristna och icke kristna, delar det moraliska samtalet på lika villkor, reser ändå hans framställning frågan om det över huvud taget är möjligt att en på detta sätt teologiskt motiverad etik - eller snarare: en teologiskt motiverad förutsättning för den ansvarets etik som utgör en kärna i människors relationer präglade av nästankärlek - kan vinna genklang också bland dem som finner det etiska kravet betydelsefullt och användbart, men utan att klä det i religiösa termer?

Den här frågan har, som den danska forskaren Pia Rose Böwadt framhållit, åtminstone två kritiska dimensioner. En rör Løgstrups starka bindande av ett liv i enlighet med det etiska kravet till en kristen skapelselära. En annan rör, som en konsekvens, frågan om det i en pluralistisk skola är rimligt att föreskriva eller i alla fall praktiskt uppmärksamma en specifik religiös hållning som önskad och, kanske också, förutsatt som giltig. (Böwadt 2009:78ff) Som Böwadt påpekar tänker sig inte Løgstrup att barn och unga ska utbildas i ett etiskt förhållningssätt präglat av tillit. Snarare är det förutsättningarna för ett sådant liv som ska stå på dagordningen. (ibid:77ff) Men givet det teologiska motiv det etiska kravet ges hos honom kan det vara svårt att se annat än att en sådan utbildning är klart konfessionell.

Jag delar inte Böwadts uppfattning fullt ut. Jag instämmer i att icke konfessionell undervisning inte ska förespråka den ena eller den andra tolkningen av vad etik och moral inbegriper på ett allmänt plan och i detaljerade tillämpningar - så länge dessa inte på ett uppenbart sätt strider mot en sådan ömsesidig respekt och empati som kommer till uttryck i moraliska principer som sammanfattas i bland annat den gyllene regeln. Men samtidigt är det betydelsefullt att barn och unga, inte minst i icke konfessionella miljöer, får möta föreställningar om hur människors etik kan förankras i en existentiell dimension som transcenderar de kontingenta, de hypotetiska och faktuellt beroende omständigheter och villkor, som bygger etiska berättiganden med referens till historiskt, kulturellt och socialt situerade motivbilder. Løgstrup pekar för övrigt själv på vikten av att lärare på ett aktivt sätt, genom beröm men också konstruktivt motstånd, inspirerar elever att utifrån sina förutsättningar och föreställningar pröva olika vägar att gå. (Løgstrup 1982) Och det är nog ett förhållningssätt som skulle kunna sägas äga relevans också och inte minst i dagens hegemoniska, sekulära värdegrundsburna etikundervisning.

En existentiellt filosofisk analys av etikens grundvillkor som den Løgstrup presenterar, skapar viktiga och potentiellt frigörande utmaningar för den som förnekar eller har svårt att se att moraliska överväganden och beslut skulle kunna ha en förankring utanför de föränderliga normernas värld, där vi alla på ett eller annat sätt upplever oss vara beroende av etisk vägledning.

Detta gäller inte bara individer utan har också en kollektiv dimension, vilket kan illustreras med svensk värdegrundspolicy i skolkontexter. Talet om en värdegrund kan tyckas ljuda aningen ihåligt om förankringen för densamma inte kan identifieras utanför en norm- och värdekontext som präglas av föränderlighet. Javisst: detta kan vara uttryck för en sansad realism inför vad som betraktas som den mänskliga moralens faktiska villkor. En sådan här uppfattning kan emellertid också utvecklas till en mer eller mindre fundamentalistisk hållning, där varje försök att finna en metafysisk, stabil grund för etisk vägledning avfärdas som orealistiskt. Realistiskt eller ej: reflektion över etikens grundläggande 
villkor är, oavsett vilka alternativ som analyseras och görs till föremål för kritisk konstruktiv belysning, moraliskt och intellektuellt frigörande. Det finns, vill jag hävda, alltför lite av sådan reflektion och analys i diskussioner kring svenskt värdegrundstänkande. (Franck 2014a)

\section{HAR DET ETISKA KRAVET PRAK- TISK RELEVANS FÖR SKOLANS VERKSAMHET?}

I de svenska läroplanerna för grund- och gymnasieskolan skrivs den demokratiska värdegrund som ska styra och prägla verksamheten fram på följande sätt:

Människolivets okränkbarhet, individens frihet och integritet, alla människors lika värde, jämställdhet mellan kvinnor och män samt solidaritet med svaga och utsatta är de värden som skolan ska gestalta och förmedla. I överensstämmelse med den etik som förvaltats av kristen tradition och västerländsk humanism sker detta genom individens fostran till rättskänsla, generositet, tolerans och ansvarstagande. Undervisningen i skolan ska vara icke-konfessionell.

Skolans uppgift är att låta varje enskild elev finna sin unika egenart och därigenom kunna delta $i$ samhällslivet genom att ge sitt bästa $i$ ansvarig frihet. (Lgr11:7, Gy11:5)3

Hur relaterar denna skrivning till Løgstrups karakteristik av det etiska kravet? Ett möjligt sätt att se på saken kan vara, att en konkret värdegrundsetik som svarar mot läroplanernas skrivningar mycket väl kan praktiseras med eller utan en medvetenhet om det etiska kravet som existentiellt given grundförutsättning för människans moraliska samliv. De värden som står i centrum för värdegrundsetiken - jämställdhet och solidaritet och andra - uppfattas generera vissa krav på hur man bör och inte bör agera i relation till medmänniskor. Skolor, och för övrigt också många andra arbetsplatser och organisationer, gör handlingsplaner, jämställdhetsplaner, likabehandlingsplaner och så vidare, och alla tjänar de syftet att reglera samvaron mellan människor på ett sätt så att ingen ska behöva uppleva sig kränkt, utesluten, exkluderad. (Fjellström 2004; Orlenius 2007; Franck 2005)

Samtidigt är det då fråga om socialt förankrade föreskrifter, där människors ömsesidighet tecknas mot bakgrund av en föreställning om prestationer och motprestationer, ageranden och re-ageranden: "om du är snäll mot mig är jag snäll mot dig", ”om du och jag låter bli att stjäla varandras saker vinner vi båda på det”. Men det etiska kravet kräver mer än en sådan socialt definierad ömsesidighet. Kravet är, minns vi, enligt Løgstrup "ensidigt": att gestalta nästankärleken är att ta andra människors liv i ens hand utan att begära någonting igen. Är inte det i så fall någonting annat än att praktisera en värdegrundsetik som vilar på rent sociala förutsättningar, där "ömsesidighet" betyder någonting annat än vad det gör när vi talar om det etiska kravets kärlekshandlingar människor emellan? Och kan då över huvud taget detta krav ha någon praktisk relevans för skolans värdegrundsbaserade verksamhet?

\section{VÄRDEGRUNDENS "GRUND"}

Jag tror att man här kan nå en brytpunkt mellan en etik förankrad i det etiska kravet och en etik som faller tillbaka på socialt förankrade normer och koder. En problematik som är relevant att lyfta fram rör det begreppet värdegrund som

3 Det kan här vara relevant att påminna om en motsvarande formulering i norska styrdokument ur §1-1 i opplæringsloven: "Opplæringa skal byggje på grunnleggjande verdiar i kristen og humanistisk arv og tradisjon, slik som respekt for menneskeverdet og naturen, på åndsfridom, nestekjærleik, tilgjeving, likeverd og solidaritet, verdiar som òg kjem til uttrykk i ulike religionar og livssyn og som er forankra i menneskerettane”. (http://lovdata.no/dokument/NL/ lov/1998-07-17-61) Också här blir det intressant att diskutera det etiska kravet i relation till vad som påstås vara en etisk intention i skolans verksamhet. 
används i läroplanerna och som under de två senaste decennierna har kommit att inta en särställning i svensk moralpedagogisk diskussion. Många har kritiskt ställt frågan vad det är för en "grund" värdegrunden egentligen antas utgöra. (Fjellström 2004; Orlenius 2004; Franck 2005) Den är inte andlig eller religiös: det skulle strida mot värdegrundsetikens icke konfessionella inriktning. Men om det inte anses vara en "Gud" eller en andlig kraft som har frambringat denna grund av värden, så måste dess förankring sökas på annat håll. Man kan givetvis försöka undvika att tala i singulära termer om "en värdegrund" eller "värdegrunden", på så vis som man gör när begreppet i den engelska översättningen av läroplanerna uttrycks som fundamental values. Men räddningen blir knappast långvarig för vad är det egentligen som gör vissa värden "grundläggande" eller "fundamentala"? Frågan om dessa värdens förankring är lika angelägen att analysera som den som rör "värdegrundens" grund. (Franck 2013a) Och här öppnar sig angelägna frågor om den "etikkens jordsmonn" vilka till exempel Svein Aage Christoffersen behandlat, och där Løgstrups betonande av att denna jordmån är något annat och djupare än de moraliska normer som så ofta i etiska diskussioner kommer att stå i fokus. (Christoffersen 1999:10ff)

En värdegrundsetik kan mycket väl motiveras på icke metafysiska grunder. Men samtidigt är det viktigt att framhålla, att hänvisningen till de sociala konventioner och överenskommelser som härvidlag tänks spela en roll kan te sig något svävande. De ger vägledning för hur människor kan och bör handla i de eller de situationerna. Men om någon ställer frågan: "Varför ska jag möta människor på det eller det sättet?”, tycks det socialt förankrade svaret inte kunna lyfta fram mer än ett behov av en mer eller mindre distanserad ömsesidighet, där prestation och motprestation existerar sida vid sida. Varje svar där den ensidiga tillämpningen av kravet i enlighet med en nästankärlek grundlägger och motiverar människors handlande mot medmänniskor, syns kräva något mer av de individer som är involverade i situationer där naturlig tillit prövas. (Franck 2013b)

Och det är här man har att ställa sig frågan: "Kan en teologiskt förankrad etik vars intention och begrepp riktas mot djupare etiska dimensioner, tillskrivas praktisk tillämpning i en sekulär och icke konfessionell utbildningskontext?" Eller är det som tidigare nämnda Böwadt tycks mena, att en sådan etik som Løgstrup företräder och som förlägger de metafysiska motiven för ett gott moraliskt samliv till kristen skapelselära, på goda grunder bör kritiseras? (Böwadt 2009:77ff)

\section{DET ETISKA KRAVET SOM KÄLLA TILL MORALISK INSPIRATION}

Den föregående framställningen har visat på Løgstrups avståndstagande från att reservera det etiska kravets tillämpning till religionens domäner. Nästankärleken på vilkens grund ensidig och oegennyttig ömsesidighet praktiseras, är inte förbehållen den som har en religiös eller specifikt kristen tro.

I princip tycks det därför inte på en praktisk nivå, när det gäller reflektion över strävan mot nästankärlek, utgöra ett problem att förena ett gestaltande av det religiöst förankrade etiska kravet och en icke konfessionell värdegrundspedagogisk etik. Men det är då ett praktiskt plan vi talar om.

I de nya kurs- och ämnesplanerna i religionskunskap finns i det centrala innehållet delar där, som det heter rörande årskurs $4-6$, "frågor om vad ett bra liv kan vara och vad det kan innebära att göra gott” ska uppmärksammas. (Lgr11:189) Här syns en diskussion kring nästankärlek i relation till religiös tro, men också andra livsåskådningar, kunna finna en plats. Varje försök att uppmuntra och motivera goda och ömsesidiga handlingar i den sekulära skolans värld med hänvisning till att det etiska kravet, som 
Løgstrup säger, är "Guds", måste däremot stanna vid att vara enbart en tanke. I samma stund som skolan beskriver sin etiska hållning och sin moral som förankrad i en gudomlig makts skapelse och dess "välsignelse" av livet som gåva, upphör den att vara icke konfessionell.

\section{SLUTSATS}

Betyder det också att dess värdegrundspedagoger måste avstå från att hänvisa till det etiska kravet när de diskuterar hur grundläggande värden ska komma till uttryck i skolans mänskliga gemenskap? Nej, vill jag svara, det betyder det inte. Men avser de därmed något mer än att socialt motivera ett ansvar för relationer byggda på skolans formella föreskrifter, behöver de sätta sig in i den kontext inom ramen för vilken Løgstrup låter det växa fram. En sådan analytisk medvetenhet är också nödvändig för att inte låta ett värdepedagogiskt berättigat intresse för det etiska kravet som livshållning, övergå i en implicit eller explicit konfessionell sanktionering av det som saknar relevans och rimlighet i en sekulär skola präglad av mångfald. Lika lite som kravets radikalitet får förringas om det ska bli begripligt, kan det i en sekulär kontext tillskrivas rollen som yttersta instans för ett gott mänskligt samliv och en god moral.

Att själv reflektera över moralens väsen och villkor, att begrunda hur långt man kan kräva att människor ska gå i sina relationer till varandra i institutionaliserade kontexter som skola och utbildning, och att för sig själv ställa frågan varför man alls ska försöka handla på ett moraliskt sätt: allt detta är frågeställningar där Løgstrups teologiskt motiverade och existentiellt fenomenologiskt förankrade etik kan inspirera till många tankar som kan leda framåt.

Att avstå från att resa sådana frågeställningar och på allvar närma sig dem, kan göra den mest välmenande värdegrundspedagog till värdegrundsfundamentalist, en sekulär moralpredikant som stelbent tolkar utvalda värden enligt påstått orubbliga principer, men som inte vill eller vågar fråga varifrån sanktionerade principer kommer. Värdegrunden blir då ett i praktiken absolutifierat och detaljreglerande moralpedagogiskt kriterium för att skilja rätt från orätt, accepterat från icke accepterat, på samma gång som den från en etiskt existentiell utgångspunkt mekaniseras såväl som instrumentaliseras.

Det är ett förhållningssätt som ligger långt från Løgstrups etiska krav. Det är också ett förhållningssätt som ligger långt från en ömsesidig, innerlig moral där människan, och inte principerna, utgör centrum.

\section{LITTERATUR}

Armgard, Lars-Olle (1993/1971). Antropologi. Problem i K. E. Løgstrups författarskap. Lund: Mattizon.

Bergem, Trygve (2000). Läraren i etikens motljus. Lund: Studentlitteratur.

Bugge, David (2011). Hinandens Verden. Ledsager til K. E. Løgstrups DEN ETISKE FORDRING. Løgstrup Biblioteket. Aarhus: Forlaget Klim.

Böwadt, Pia Rose (2009). "Education of Life Itself. A Discussion of Lebensphilosophie, Education and Religious Education According to K. E. Løgstrup and O. F. Bollnow”, i Skeie, Geir (red): Religious Diversity and Education. Nordic Perspectives. Münster: Waxmann, s 69-82.

Christoffersen, Svein Aage (1999). Etikk, eksistens og modernitet. Innføring i Løgstrups tenkning. Oslo: Tano Aschehoug.

Fjellström, Roger (2004). Skolområdets etik. En studie i skolans fostran. Lund: Studentlitteratur. Franck, Olof (2005). Den goda människan och värdegrunden. Demokratins värden och det integrera(n)de medborgarskapet. Integrationsverkets stencilserie 2005:02. Norrköping: 
Integrationsverket.

Franck, Olof (2006). ”Det osynliga Eden - om religionsblindhet och skola", i S A Flodell (red): Religionsblindhet, Stiftelsen Sverige och kristen tro, Bromma s 119-134.

Franck, Olof (2013a). "Veta rätt och göra gott - etik som didaktiskt kunskapsområde", i Franck, Olof (red): Samhällsämnenas didaktik. Åk 4-6. Lund: Studentlitteratur s 91-122.

Franck, Olof (2013b). ”Etisk litteracitet - om filosofiska förutsättningar för att utveckla ämnesdidaktiska perspektiv med hänsyn till kursplanen i religionskunskap (Lgr11)”, i Marner, Anders \& Örtegren, Hans (red): KLÄM. Konferenstexter om Lärande, Ämnesdidaktik och Mediebruk. Tilde skriftserie nr. 1, Institutionen för estetiska ämnen, Umeå universitet, s 178-197).

Franck, Olof (2014a). "Värdegrunden som kanon: stöd eller börda?, i Franck, Olof (red): Motbok. Kritiska perspektiv på styrdokument, lärarutbildning och skola, Lund: Studentlitteratur s 195-218.

Franck, Olof (2014b). "Sekulär undervisning om religiöst motiverad etik - om motstånd, underkastelse och emancipation", $i$ Religion og livssyn 2/2014. (Publiceras hösten 2014.)

Gren, Jenny (2007). Etik $i$ pedagogiskt vardagsarbete. Stockholm: Liber.

Hansen, Karstein M. (1996). Skapelse og kritikk. Skapelsestankens kritiske funksjon $i$ K. E. Løgstrups forfatterskap med scerlig henblikk på den unge Løgstrup. Oslo: Universitetsforlaget

Hansson, Susanne (2012). Den nödvändiga osäkerheten - Elevers perspektiv på respekt $i$ relationer $i$ skolan. Karlstad University Studies 2012:10. Karlstad 2012. http:// www.diva-portal.org/smash/get/diva 2:507169/FULLTEXT01

Lilja, Annika (2013). Förtroendefulla relationer mellan lärare och elev. GÖTEBORG
STUDIES IN EDUCATIONAL SCIENCES

338. Göteborgs universitet: ACTA UNIVERSITATIS GOTHOBURGENSIS.

Lov om grunnskolen og den vidaregåande oppleringa (opplceringslova), Kunnskaps-departementet, LOV-2014-06-20-54 fra 01.08.2014. (http:// lovdata.no/dokument /NL/lov/1998-07-1761).

Läroplan för grundskolan, förskoleklassen och fritidshemmet 2011. Skolverket. Stockholm: Fritzes.

Läroplan, examensmål och gymnasie-gemensamma ämnen för gymnasieskola 2011. Skolverket. Stockholm: Fritzes.

Løgstrup, Knud Ejler (2009/1956). Det etiska kravet. Sv övers: Margareta Brandby-Cöster. Göteborg: Daidalos.

Løgstrup, Knud Ejler (1997/1982). System og symbol. Essays. København: Gyldendal.

Løgstrup, Knud Ejler (1961). Kunst og etik. Køpenhamn: Gyldendal.

Orlenius, Kennert (2010). Värdegrunden - finns den? Stockholm: Liber.

Sädbom, Rebecka (2007). ”I en del av lärares vardag - det etiska handlandet och dess relation till intuition-i-aktion som existerande yrkesskicklighet”. Didaktisk Tidskrift, Vol 17, No. 3, 2007. http://www.didaktisktidskrift. se/pdf/sadbom.pdf

Särdquist, Esbjörn (2010). Kunskapens yttersta kant. Gud och det givna i K.E. Løgstrups Metafysik. Skellefteå: Artos \& Norma Bokförlag.

Van Kooten Niekerk, Kees (2007). ”Vejen til Den etiske fordring", i David Bugge \& Peter Aaboe Sørensen (red): Livtag med den etiske fordring. Aarhus: Forlaget Klim s 9-46.

Wingren, Gustaf (2009). "Förord till den svenska utgåvan”, i Løgstrup, Knud Ejler: Det etiska kravet. Sv övers: Margareta Brandby-Cöster. Göteborg: Daidalos, s 9-33. 